\title{
Pandemic influenza A(H1N1)2009: molecular characterisation and duration of viral shedding in intensive care patients in Bordeaux, south-west France, May 2009 to January 2010
}

\author{
L Malato ${ }^{1,2}$, V Llavador ${ }^{1,2}$, E Marmier ${ }^{1}$, J Youssef ${ }^{3}$, C Balick Weber $^{3}$, H Rozée $^{3}$, E Bessede ${ }^{4}$, H J Fleury \\ (herve.fleury@viro.u-bordeaux2.fr)'1 \\ 1. Virology laboratory, University Hospital of Bordeaux, France \\ 2. These authors contributed equally to this work \\ 3. Intensive care units (Hospitals St André, Pellegrin and Haut Lévèque), University Hospital of Bordeaux, France \\ 4. Bacteriology Laboratory, University Hospital of Bordeaux, France
}

Citation style for this article

Malato L, Llavador V, Marmier E, Youssef J, Balick Weber C, Rozé H, Bessede E, Fleury HJ. Pandemic influenza A(H1N1)2009: molecular characterisation and duration of viral shedding in intensive care patients in Bordeaux, south-west France, May 2009 to January 2010. Euro Surveill. 2011;16(4):pii=19776. Available online: http:// www.eurosurveillance.org/ViewArticle.aspx?Articleld=19776

Article published on 27 January 2011

From May 2009 to January 2010, the Virology Laboratory at the University Hospital of Bordeaux received more than 4,000 nasopharyngeal samples from the Aquitaine region (south-west France) for the diagnosis of pandemic influenza $A\left(\mathrm{H}_{1} \mathrm{~N}_{1}\right)_{2009}$. Eightythree infected patients deteriorated and were admitted to intensive care units. Our study focused on 24 of these patients. Positivity for influenza $\mathrm{A}\left(\mathrm{H}_{1} \mathrm{~N}_{1}\right)_{2009}$ was monitored by realtime PCR and duration of viral shedding was determined. The first available sample of each patient was analysed for bacterial, fungal and viral co-infection. We observed six bacterial (or bacterial/fungal) co-infections and one viral co-infection with respiratory syncytial virus. The samples were analysed for the presence of the neuraminidase $\mathrm{H} 275 \mathrm{Y}$ (N1 numbering) mutation, which confers resistance to oseltamivir, by realtime PCR of the neuraminidase gene. No $\mathrm{H}_{275} \mathrm{Y}$ mutation was observed in any of the viral strains screened in this study. In parallel, a fragment of the haemagglutinin gene encoding amino acid residues 173 to 362 was sequenced to detect mutations that had been reported to increase the severity of the disease. Two patients were infected by strains bearing the $\mathrm{D}_{222 \mathrm{G}}$ ( $\mathrm{H}_{3}$ numbering) mutation. The viral shedding of $A\left(\mathrm{H}_{1} \mathrm{~N}_{1}\right)_{2009}$ in this study ranged from four to 28 days with a median of 11 days.

\section{Introduction}

During the influenza $A\left(\mathrm{H}_{1} \mathrm{~N}_{1}\right) 2009$ pandemic, the virology laboratory at the University Hospital of Bordeaux received from May 2009 to January 2010 more than 4,000 samples collected from the Aquitaine region (south-west France), an area with three million inhabitants. Some 1002 (24.9\%) samples were confirmed as positive for pandemic influenza $A\left(\mathrm{H}_{1} \mathrm{~N}_{1}\right)_{2009}$ by realtime PCR. During this period, the three intensive care units (ICUs) of the University Hospital of Bordeaux received 83 patients with severe clinical conditions including acute respiratory distress syndrome (ARDS).
Six of them required extracorporeal membrane oxygenation (ECMO) support. We could study those six and an additional 18 influenza-positive ICU patients in detail to address the following points: to establish the presence of microbial co-infection on admission, to obtain molecular data on the oseltamivir resistanceassociated $\mathrm{H}_{275} \mathrm{Y}$ mutation [1] in the neuraminidase gene, to screen for already identified mutations in the haemagglutinin ( $\mathrm{HA}$ ) gene that may have an influence on the virulence of the virus [2-5], and to evaluate the duration of viral shedding.

\section{Methods}

Patients with confirmed influenza $A\left(\mathrm{H}_{1} \mathrm{~N}_{1}\right) 2009$ were selected retrospectively for this study after their admission to the ICU for influenza complications, for example respiratory failure or exacerbation of an underlying chronic condition requiring surveillance or assistance. The patients in this study were admitted to the ICU between May 2009 and January 2010.

The detection of influenza $A\left(\mathrm{H}_{1} \mathrm{~N}_{1}\right) 2009$ viral RNA was carried out in nasal swabs, bronchoalveolar lavage fluids or respiratory secretions. Pandemic influenza $\mathrm{A}\left(\mathrm{H}_{1} \mathrm{~N}_{1}\right) 2009$ was diagnosed using the Roche detection kit for influenza A (RealTime ready Influenza $A\left(\mathrm{H}_{1} \mathrm{~N}_{1}\right)$ detection set) and operated on a Roche LightCycler 480 .

We screened each patient at admission for viral, bacterial and fungal co-infections. Viral respiratory co-infections were investigated using a multiplex PCR assay (Seegene Seeplex RV5-ACE screening) which allows the detection of influenza $A$, influenza $B$, respiratory syncytial virus (RSV) $A / B$, adenovirus $A / B / C / D / E$, parainfluenzavirus $1 / 2 / 3$, bocavirus 1 , metapneumovirus, human rhinovirus and coronavirus $\mathrm{OC}_{43} / 229 \mathrm{E} / \mathrm{NL} 63 /$ HKU1. Bacterial and fungal co-infections were diagnosed after culture and/or serology. 
The $\mathrm{H}_{275} \mathrm{Y}$ ( $\mathrm{N}_{1}$ numbering) mutation conferring resistance to oseltamivir was investigated on admission on the first specimen by a fluorescence resonance energy transfer (FRET)-based assay designed in the virology laboratory in Bordeaux as previously described [6].

For sequencing of the HA gene, influenza A RNA was reverse-transcribed using the Titan One Tube RT-PCR kit (Roche) with primers $\mathrm{HA} 1 \mathrm{~S}$ (ATGAAGGCAATACTAGTAGTTATGCTATATAC) and HA1AS (TTAAATACATATTCTACACTGTAGAGACCC). cDNA was then subjected to a nested PCR to amplify a fragment encoding for amino acid residues 173-362 with primers $\mathrm{HA}_{3} \mathrm{~S}$ (CCAAAGCTCAGCAAATCCTAC) and HA3AS (ATCTCGTCAATGGCATTCTGT). The sequences were aligned to the reference strain A/California/06/2009 using Clustalw and Jalview softwares.

Duration of viral shedding was determined as the period between the onset of symptoms and the last positive $P C R$ for influenza $A\left(\mathrm{H}_{1} \mathrm{~N}_{1}\right)_{2009}$ with exception of some cases for whom onset of symptoms could not be determined (the first positive PCR being used as Do of viral shedding). As there was no standard protocol for the follow-up of influenza patients, sampling could have stopped while the patients were still positive for influenza $A\left(\mathrm{H}_{1} \mathrm{~N}_{1}\right)_{2009}$. Using such a method we may have underestimated the duration of the shedding but were not dependent on a negative PCR to evaluate the shedding.

\section{Results}

We studied 24 patients admitted to the ICU for severe influenza $A\left(\mathrm{H}_{1} \mathrm{~N}_{1}\right) 2009$ between May 2009 and January 2010. All the data collected are summarised in Table 1. The patients had a median age of 51.5 years ranging from 2 to 85 years and the female:male sex ratio was 0.45 . Eight patients were immunocompromised (one with lung carcinoma with metastasis, one with co-infection with human immunodeficiency virus (HIV) and hepatitis C virus (HCV), two with leukaemia, two with lymphoma and two patients under follow-up for transplantation), seven had chronic cardiovascular and/or pulmonary diseases, four were obese (BMI>30), and nine had no comorbidity. During the study four patients died.

We were able to collect data concerning antiviral treatment for 20 of the 24 patients. The 20 patients had received the neuraminidase inhibitor oseltamivir. The median time of oseltamivir treatment initiation in the 17 patients for whom this information was available, was five days after the onset of symptoms (range: 1-12 days).

Screening on admission for microbial co-infections revealed only one viral co-infection with respiratory syncytial virus (RSV) and six bacterial or fungal co-infections: Staphylococcus aureus, Haemophilus influenzae, Streptococcus agalactiae, Branhamella catarrhalis,
Enterobacter cloacae, Mycoplasma pneumoniae and Candida albicans (Table 1)

We were able to follow up positivity for influenza $A\left(H_{1} N_{1}\right) 2009$ viral RNA in 18 patients for whom we had several specimens. The median duration of viral shedding was 11 days (4-28 days, Table 2). Immunodepression was associated with prolonged viral shedding, with six of the eight immunocompromised patients PCR-positive 14 or more days after onset of symptoms (Table 1); the two other patients who also shed virus for longer than 14 days were obese. Immunocompetent and immunocompromised patients shed virus for a median duration 10 days and 16 days, respectively.

The $\mathrm{H}_{275} \mathrm{Y}$ mutation was not detected in any of our patients, nor was any other mutation at position 275 of the neuraminidase gene.

We amplified 26 HA sequences from 21 patients (two patients were investigated with several successive samples). The different substitutions of our isolates compared to the reference strain are shown in the Figure. Three samples from two different patients exhibited the D222G substitution. The first (Patient 1 in Table 1) was a patient with morbid obesity (body mass index>40) presenting a severe ARDS requiring ECMO support for nine days and mechanical ventilation for a further 20 days. The HA sequence of virus isolated from their bronchoalveolar lavage fluid showed a mixed population at codon 222: D222EG. As shown in Table 1, she exhibited prolonged viral shedding of 28 days (already published [7]) but recovered and was discharged after one month. The second case (Patient 8 in Table 1) had a lymphoma and chronic obstructive pulmonary disease. Viral shedding lasted for a minimum of 14 days (from the first to the last positive sample), and the patient died after 19 days of hospitalisation. Four influenza A-positive samples from this patient were subjected to HA sequencing. The first sample, a nasal swab, did not contain the D222G substitution, nor did the second one which was a respiratory secretion. Interestingly, the D222G was identified in the third and fourth specimens obtained from secretions 12 and 14 days after the first sample. A mixed population (D222DG) was noted in the fourth specimen. In addition to the $\mathrm{D} 222 \mathrm{G}$ mutation, isolates from all four samples contained a $V_{321} \mathrm{~F}$ substitution in HA that did not match any HA sequences published as of May 2010.

Other substitutions are listed in Table 3 and include S203T (13/26 sequences), and less frequently D222E (4/26), Y230H (1/26), M257l (1/26), Q293H (1/26), I295V (2/26), K305R (1/26), $\mathrm{V}_{321 \mathrm{l}}(2 / 26)$ and $\mathrm{V}_{321} \mathrm{~F}(5 / 26)$.

\section{Discussion}

In Aquitaine, $13-25 \%$ of the population were infected with influenza $A\left(\mathrm{H}_{1} \mathrm{~N}_{1}\right) 2009$ during the pandemic [8].. Between May 2009 and January 2010, 83 patients suffered from a complicated influenza and were admitted 


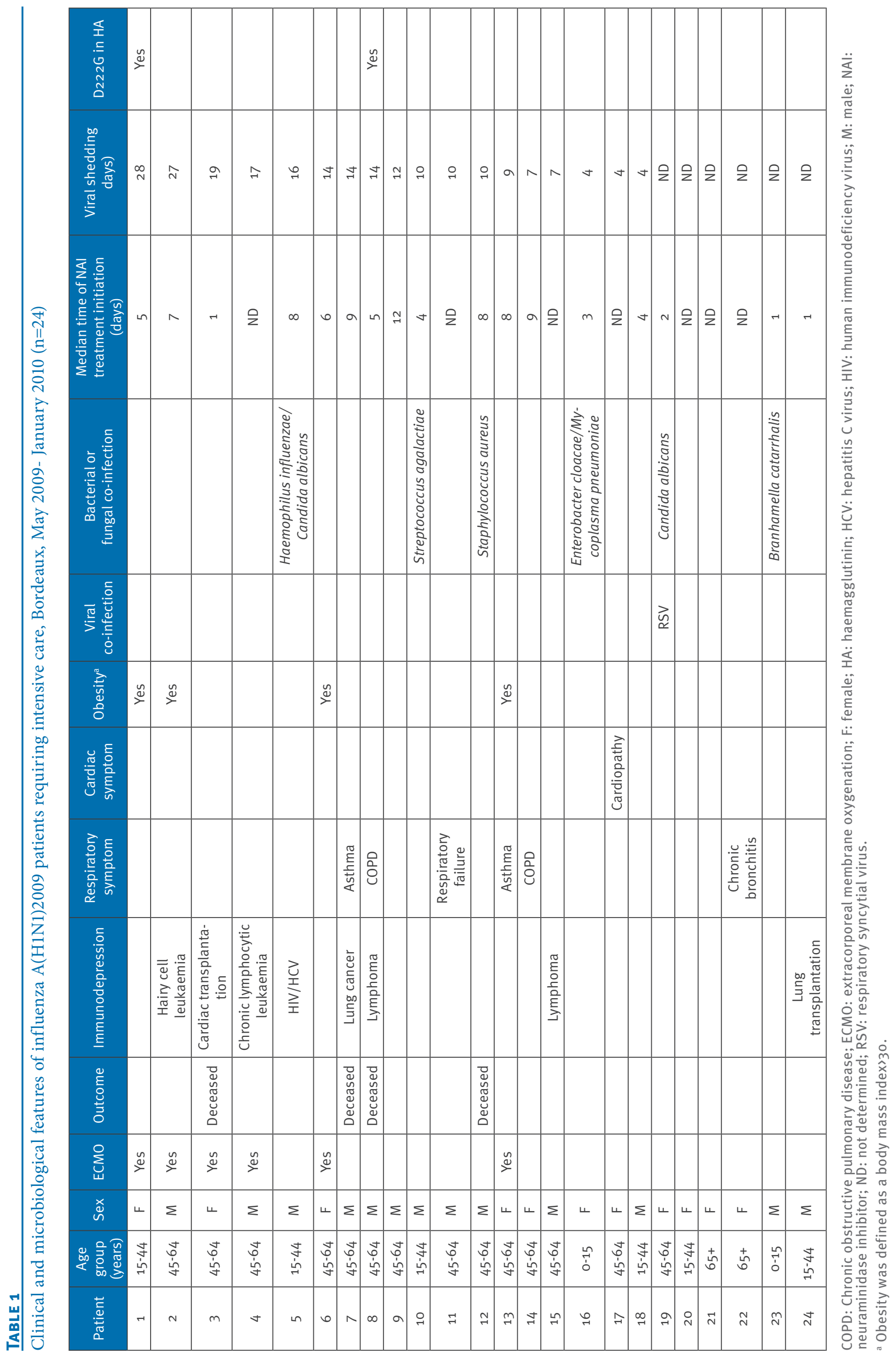


to an ICU. Influenza $\mathrm{A}\left(\mathrm{H}_{1} \mathrm{~N}_{1}\right)_{2009}$ has been widely reported to affect subjects younger than those usually affected by seasonal influenza, i.e. people over than 65 years of age or with underlying chronic conditions $[9,10]$. This is in accordance with the 24 severely ill patients in our study who had a median age of 51 years. While one third of them (9/24) did not have an identified risk factor for influenza, the remaining two thirds were either immunocompromised or presented with underlying respiratory and/or cardiac disease or were obese.

While ARDS was also observed in previous seasonal influenzas, it was more frequent with the pandemic influenza $A\left(\mathrm{H}_{1} \mathrm{~N}_{1}\right) 2009$ virus strain. ARDS was responsible for $36-96 \%$ of admissions to ICUs during the pandemic [11-14] and might account for the increased need for ECMO support [15]. Among the 83 critically ill patients in Aquitaine, ARDS was involved in 57 [8]. Seven of the 83 received ECMO support for a median duration of 16 days, and six of those were included in the present study. Patients under ECMO in this study were either immunocompromised and/or obese. This is in line with other studies that identified obesity as a comorbidity for influenza $A\left(\mathrm{H}_{1} \mathrm{~N}_{1}\right) 2009$, as already noted in previous studies $[13,16,17]$.

Our patients were screened on admission to the ICU for microbial co-infections that could increase the severity of the influenza. Viral co-infection was scarce: one case of influenza/RSV co-infection was seen in a patient in their $60 s$ with no risk factors. In addition, we found six bacterial/fungal co-infections, the majority of which were not acquired in the hospital. While one of them, Patient 12, died of fatal septicaemia caused by a $S$. aureus infection, there was no suspicion that the bacterial co-infection had an effect on the severity of influenza in the five remaining patients. A recent study reported that the role of bacterial co-infection in the need for ICU admission is not clear, but that the virus is the cause of critical illness in the vast majority of cases [18].

The median duration of viral shedding was 11 days in our study, which is longer than the five to seven days

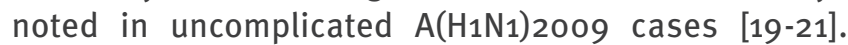
Eight of the nine patients shedding virus particles for longer than the median had an identified risk factor, among others immunodepression and/or obesity that are considered as a poor prognostic factor. However, the ninth patient had no comorbidity. It is widely accepted that the period of shedding of influenza virus is longer in immunocompromised patients $[19,20]$. Interestingly, viral shedding was longer in patient 1 (with a 28-day peak) whose immunological status was normal but who was obese. Furthermore, patients with ECMO or with a fatal outcome had longer viral shedding values than others.

The patients included in this study had been treated with the neuraminidase inhibitor oseltamivir. The

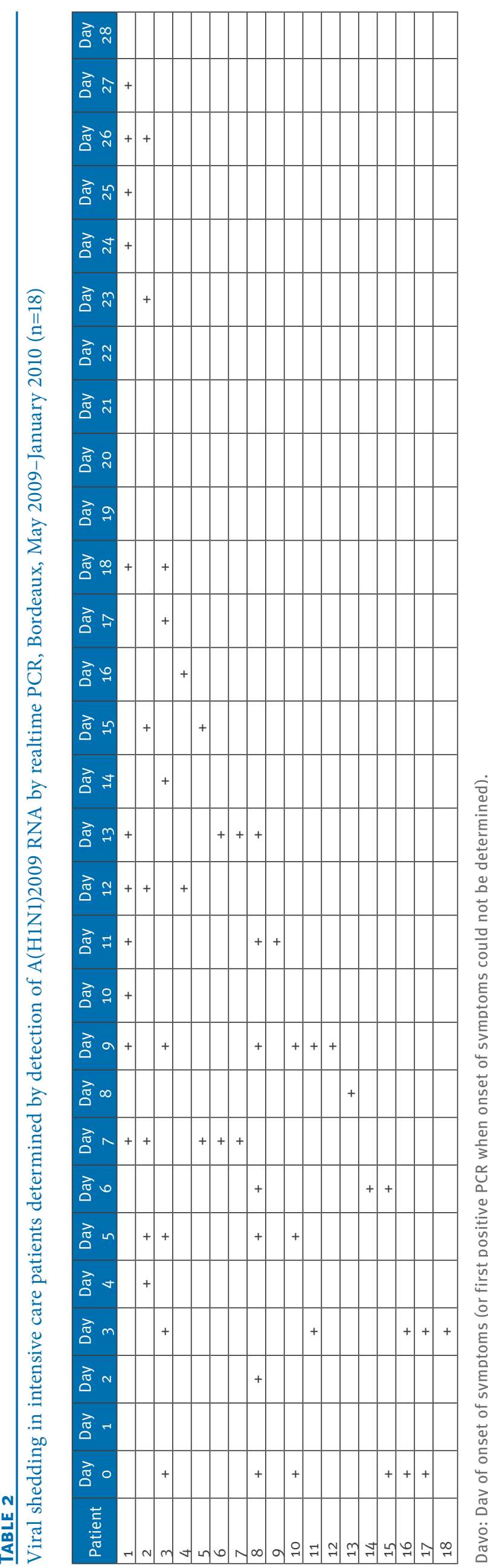




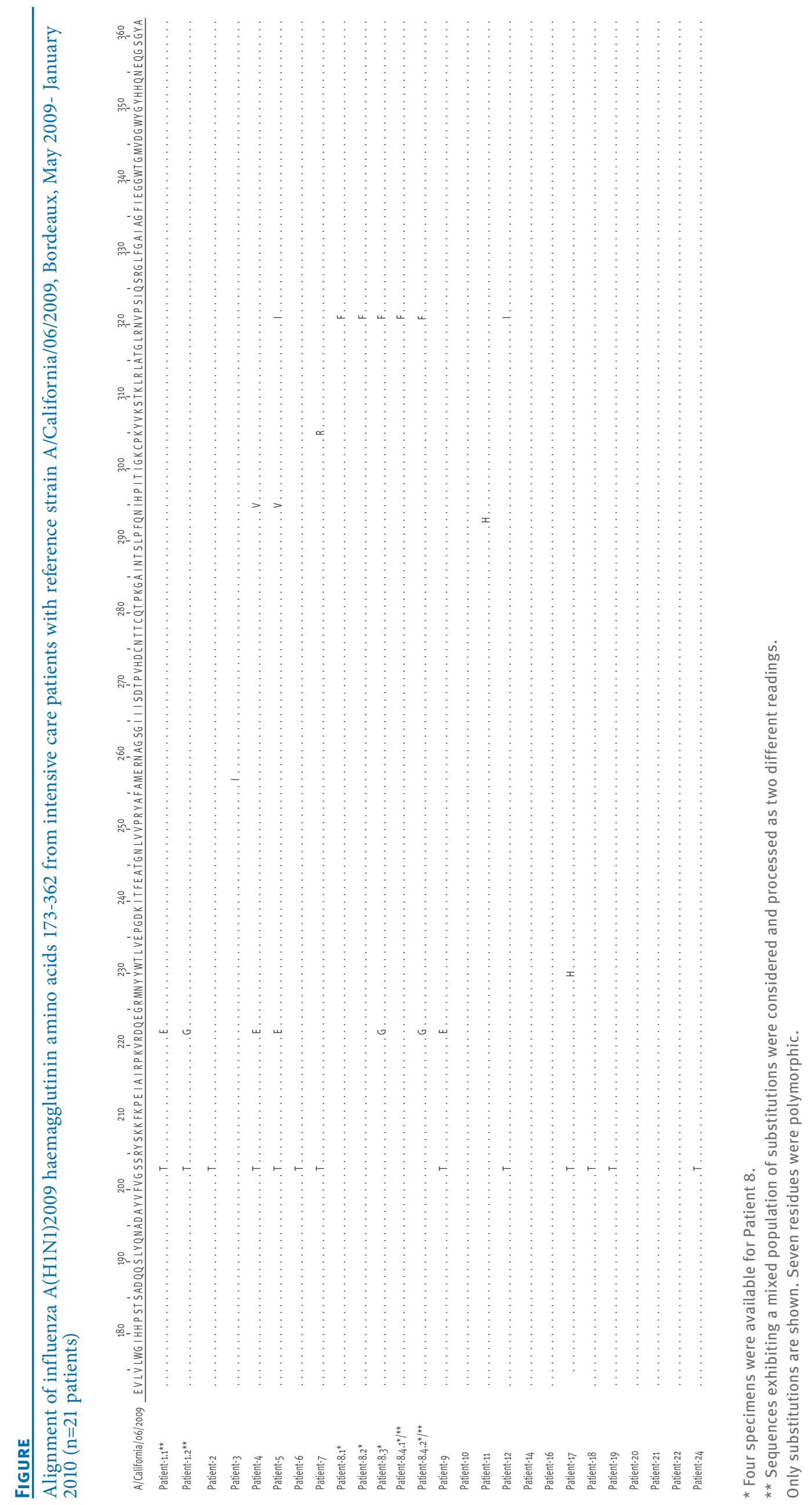


median delay before initiation of treatment was five days, which exceeds the recommended time for the administration of oseltamivir at the latest 48 hours after the onset of symptoms [22]. Late treatment due to delayed admission to the ICU and comorbidities could account for prolonged viral shedding because of a slower viral clearance [23]; it has been shown that treatment initiated one to three days after infection significantly shortens viral shedding duration [24]. However, Patient 3 was shedding virus particles for 19 days despite rapid administration of oseltamivir.

As among the currently licensed drugs only neuraminidase inhibitors remain useful to treat influenza $\mathrm{A}\left(\mathrm{H}_{1} \mathrm{~N}_{1}\right)_{2009}$, it is of particular importance to monitor the resistance/sensitivity of viral isolates to oseltamivir. Unfortunately worrying levels of oseltamivir-resistant isolates of the seasonal influenza $A\left(\mathrm{H}_{1} \mathrm{~N}_{1}\right)$ have emerged in Europe $[25,26]$. In these viruses, the most frequent mutation conferring resistance to oseltamivir is the $\mathrm{H}_{275} \mathrm{Y}$ substitution [27] in the neuraminidase gene, which does not cause cross-resistance to zanamivir.

Among the 26 isolates analysed, we have not observed any $\mathrm{H}_{275} \mathrm{Y}$ substitution. These data are in accordance with the literature showing that the prevalence of resistant $A\left(\mathrm{H}_{1} \mathrm{~N}_{1}\right)_{2009}$ viruses is at present very low. As of August 2010, 304 cases of oseltamivir resistance in this strain have been reported worldwide [28], all of which were due to the $\mathrm{H}_{275} \mathrm{Y}$ mutation in NA.

The HA protein is one of the determinants of virulence and host specificity through it's interaction with the sialic acid receptor on the cell surface. While avian influenza viruses preferentially bind to alpha2,3-linked sialic acid, human viruses prefer the alpha2,6 linkage [29]. It has been shown that two positions in HA are involved in determining sialic acid binding preference, namely amino acid residues 187 and 222 (190 and 225 in $\mathrm{H}_{3}$ numbering) [30]. A D222G mutation causes

\section{TABLE 3}

Frequency of haemagglutinin substitutions identified in influenza A(H1N1)2009 isolates from intensive care patients, Bordeaux, May 2009- January 2010 ( $n=21$ patients)

\begin{tabular}{|l|c|c|}
\hline Mutations in HA & $\begin{array}{c}\text { Frequency (among } \\
\text { the 26 sequences) }\end{array}$ & $\begin{array}{c}\text { Number of patients exhibit- } \\
\text { ing this mutation }\end{array}$ \\
\hline S203T & $50 \%$ & 12 \\
\hline D222G & $8 \%$ & 2 \\
\hline D222E & $15 \%$ & 4 \\
\hline Y230H & $4 \%$ & 1 \\
\hline M257l & $4 \%$ & 1 \\
\hline Q293H & $4 \%$ & 1 \\
\hline I295V & $8 \%$ & 2 \\
\hline K305R & $4 \%$ & 1 \\
\hline V321 & $8 \%$ & 2 \\
\hline V321F & $19 \%$ & 1 \\
\hline
\end{tabular}

HA: haemagglutinin. a shift to preferential binding to alpha2,3 receptors. This mutation has recently been described in influenza $A\left(\mathrm{H}_{1} \mathrm{~N}_{1}\right)_{2009}$ isolates from patients with severe disease or fatal outcome in several countries [2,4,5,31,32], but has also been detected in association with a mild disease [33].

Two D222G substitutions were observed in our study. Both patients experienced a severe clinical course of disease. One required ECMO and the estimated viral shedding lasted 28 days [7], while the other died after 19 days and was at the time probably still positive for influenza $\mathrm{A}\left(\mathrm{H}_{1} \mathrm{~N}_{1}\right)_{2009}$, although no autopsy was performed. In the deceased patient, this mutation was not present on admission but appeared 12 days after the first positive sample, therefore suggesting a selection event. We propose that the long duration of viral shedding allowed the virus to evolve and acquire this substitution. Whether or not this mutation accounted for the severity of the disease in this patient remains to be investigated.

Interestingly, the 1918 Spanish influenza isolate NY18 carried the combination D190/G225 and had double specificity for both alpha2,3- and alpha2,6-linked sialic acid [30]. It has been shown in ferrets that this viral isolate fails to transmit efficiently but remains virulent $[30,34]$. Alpha2,3 sialic acid receptors are found in the lower respiratory tract in humans [35]. Like the avian influenza $\mathrm{A}\left(\mathrm{H}_{5} \mathrm{~N}_{1}\right)$ virus, strains with mutations that affect receptor binding might be less efficiently transmitted but could have an increased pathogenicity [4].

In addition to the D222G substitution, we observed four D222E substitutions in this study (Table 3, Figure). Although these patients had prolonged viral shedding, we could not clearly establish a link with the severity of the disease as they all, except Patient 9, presented comorbidities. Studies have shown that the proportion of D222E is similar in mild and severe cases [32].

In parallel, we found $\mathrm{Q} 293 \mathrm{H}$ and $1295 \mathrm{~V}$ mutations whose pejorative role has been mooted but remains to be confirmed [3].

\section{Conclusion}

In 24 patients hospitalised in the ICU for pandemic influenza $\mathrm{A}\left(\mathrm{H}_{1} \mathrm{~N}_{1}\right) 2009$ infection, the requirement for ECMO was mainly associated with comorbidities (immunodepression/pulmonary disease/obesity) and long viral shedding despite oseltamivir treatment.

All strains were found susceptible to oseltamivir. The D222G substitution was observed in only two patients and we hypothesise that this mutation is selected for in the lower respiratory tract but is not transmitted. Microbial co-infections were detected, but with one exception it was not clear whether they contributed to the severity of the disease. We think that the influenza virus alone was responsible for the severe disease and the evolution toward ARDS. 


\section{References}

1. Baz M, Abed Y, Simon P, Hamelin M, Boivin G. Effect of the neuraminidase mutation $\mathrm{H}_{274} \mathrm{Y}$ conferring resistance to oseltamivir on the replicative capacity and virulence of old and recent human influenza $\mathrm{A}\left(\mathrm{H}_{1} \mathrm{~N}_{1}\right)$ viruses. J Infect Dis. 2010;201(5):740-5.

2. Antón A, Marcos MA, Martínez MJ, Ramón S, Martínez A, Cardeñosa N, et al. D225G mutation in the hemagglutinin protein found in 3 severe cases of 2009 pandemic influenza $A$ $\left(\mathrm{H}_{1} \mathrm{~N}_{1}\right)$ in Spain. DiagnMicrobiol Infect Dis. 2010;67(2):207-8.

3. Glinsky GV. Genomic analysis of pandemic ( $\left.\mathrm{H}_{1} \mathrm{~N}_{1}\right) 2009$ reveals association of increasing disease severity with emergence of novel hemagglutinin mutations. Cell Cycle. 2010;9(5):958-70.

4. Liu Y, Childs RA, Matrosovich T, Wharton S, Palma AS, Chai W, et al. Altered receptor specificity and cell tropism of D222G hemagglutinin mutants isolated from fatal cases of pandemic $A\left(\mathrm{H}_{1} \mathrm{~N}_{1}\right) 2009$ influenza virus. J Virol. 2010;84(22):12069-74.

5. Mak GC, Au KW, Tai LS, Chuang KC, Cheng KC, Shiu TC, et al. Association of D222G substitution in haemagglutinin of 2009 pandemic influenza $A\left(\mathrm{H}_{1} \mathrm{~N}_{1}\right)$ with severe disease. Euro Surveill. 2010;15(14):pii=19534. Available from: http://www. eurosurveillance.org/ViewArticle.aspx?Articleld=19534

6. Burrel S, Roncin L, Lafon ME, Fleury H. Oseltamivir susceptibility in south-western France during the 2007-8 and 2008-9 influenza epidemics and the ongoing influenza pandemic 2009. Euro Surveill. 2009;14(38): pii=19334. Available from: http://www.eurosurveillance.org/ViewArticle. aspx?Articleld $=19334$

7. Fleury H, Burrel S, Balick Weber C, Hadrien R, Blanco P, Cazanave $C$, et al. Prolonged shedding of influenza $A\left(\mathrm{H}_{1} \mathrm{~N}_{1}\right)$ v virus: two case reports from France 2009. Euro Surveill. 2009;14(49):pii=19434. Available from: http://www. eurosurveillance.org/ViewArticle.aspx?Articleld=19434

8. Bilan épidémiologique de la grippe $\mathrm{A}\left(\mathrm{H}_{1} \mathrm{~N}_{1}\right)_{2} 009$ en Aquitaine, 2009-2010. [Epidemiological assessment of influenza $\mathrm{A}\left(\mathrm{H}_{1} \mathrm{~N}_{1}\right) 2009$ in Aquitaine, 2009-2010]. Bulletin de veille sanitaire. 2010;5. Paris: Institut de Veille Sanitaire; August 2010. Available from: http://www.invs.sante.fr/publications/ bvs/aquitaine/2010/bvs_aquitaine_2010_05.pdf

9. Chowell G, Bertozzi SM, Colchero MA, Lopez-Gatell H, AlpucheAranda $C$, Hernandez $M$, et al. Severe respiratory disease concurrent with the circulation of $\mathrm{H}_{1} \mathrm{~N}_{1}$ influenza. N Engl J Med. 2009;361(7):674-9.

10. Sullivan SJ, Jacobson RM, Dowdle WR, Poland GA. $2009 \mathrm{H}_{1} \mathrm{~N}_{1}$ influenza. Mayo Clin Proc. 2010;85(1):64-76.

11. ANZIC Influenza Investigators, Webb SA, Pettilä V, Seppelt I, Bellomo R, Bailey M, et al. Critical care services and 2009 $\mathrm{H}_{1} \mathrm{~N}_{1}$ influenza in Australia and New Zealand. N Engl J Med. 2009;361(20):1925-34.

12. Kumar A, Zarychanski R, Pinto R, Cook DJ, Marshall J, Lacroix J, et al. Critically ill patients with 2009 influenza $A\left(\mathrm{H}_{1} \mathrm{~N}_{1}\right)$ infection in Canada. JAMA. 2009;302(17):1872-9.

13. Rello J, Rodríguez A, Ibañez P, Socias L, Cebrian J, Marques $A$, et al. Intensive care adult patients with severe respiratory failure caused by Influenza $A\left(\mathrm{H}_{1} \mathrm{~N}_{1}\right) v$ in Spain. Crit Care. 2009;13(5):R148.

14. Domínguez-Cherit G, Lapinsky SE, Macias AE, Pinto R, Espinosa-Perez L, de la Torre A, et al. Critically ill patients with 2009 influenza $\mathrm{A}\left(\mathrm{H}_{1} \mathrm{~N}_{1}\right)$ in Mexico. JAMA. 2009;302(17):1880-7.

15. Davies A, Jones D, Bailey M, Beca J, Bellomo R, Blackwell $\mathrm{N}$, et al. Extracorporeal membrane oxygenation for 2009 influenza $\mathrm{A}\left(\mathrm{H}_{1} \mathrm{~N}_{1}\right)$ acute respiratory distress syndrome. JAMA. 2009;302(17):1888-95.

16. Centers for Disease Control and Prevention (CDC).Hospitalized Patients with novel influenza $A\left(\mathrm{H}_{1} \mathrm{~N}_{1}\right)$ virus infection California, April-May, 2009. MMWR Morb Mortal Wkly Rep. 2009;58(19):536-41.

17. Díaz E, Rodríguez A, Martin-Loeches I, Lorente L, Del Mar Martín M, Pozo JC, et al. Impact of obesity in patients infected with new influenza $A\left(\mathrm{H}_{1} \mathrm{~N}_{1}\right) \mathrm{v}$. Chest. 2010 Aug 5. [Epub ahead of print].

18. Martín-Loeches I, Sanchez-Corral A, Diaz E, Granada R, Zaragoza R, Villavicencio C, et al. Community-acquired respiratory co-infection (CARC) in critically ill patients infected with pandemic 2009 influenza $A\left(\mathrm{H}_{1} \mathrm{~N}_{1}\right)$ virus infection. Chest. 2010 Oct 7. [Epub ahead of print].

19. Novel Swine-Origin Influenza $A\left(\mathrm{H}_{1} \mathrm{~N}_{1}\right)$ Virus Investigation Team, Dawood FS, Jain S, Finelli L, Shaw MW, Lindstrom S, et al. Emergence of a novel swine-origin influenza $A\left(\mathrm{H}_{1} \mathrm{~N}_{1}\right)$ virus in humans. N Engl J Med. 2009;360(25):2605-15.

20. Cao B, Li X, Mao Y, Wang J, Lu H, Chen Y, et al. Clinical features of the initial cases of 2009 pandemic influenza $A\left(\mathrm{H}_{1} \mathrm{~N}_{1}\right)$ virus infection in China. N Engl J Med. 2009;361(26):2507-17.
21. Cowling BJ, Chan KH, Fang VJ, Lau LL, So HC, Fung RO, et al. Comparative epidemiology of pandemic and seasonal influenza A in households. N Engl J Med. 2010;362(23):2175-84.

22. Aoki FY, Macleod MD, Paggiaro P, Carewicz O, El Sawy A, Wat $C$, et al. Early administration of oral oseltamivir increases the benefits of influenza treatment. J Antimicrob Chemother. 2003;51(1):123-9.

23. Na S, Chong YP, Kim MN, Kim WY, Kim W, Hong SB, et al. Duration of viral shedding in patients admitted to hospital with pandemic influenza A/H1N1 2009 infection. J Med Virol. 2011;83(1):5-9.

24. Ling LM, Chow AL, Lye DC, Tan AS, Krishnan P, Cui L, et al. Effects of early oseltamivir therapy on viral shedding in 2009 pandemic influenza $A\left(\mathrm{H}_{1} \mathrm{~N}_{1}\right)$ virus infection. Clin Infect Dis. 2010;50(7):963-9.

25. Meijer A, Lackenby A, Hungnes O, Lina B, van-der-Werf S, Schweiger B, et al. Oseltamivir-resistant influenza virus $A\left(\mathrm{H}_{1} \mathrm{~N}_{1}\right)$, Europe, 2007-08 season. Emerging Infect Dis 2009;15(4):552-60.

26. Hurt AC, Holien IK, Parker MW, Barr IG. Oseltamivir resistance and the $\mathrm{H}_{2} 74 \mathrm{Y}$ neuraminidase mutation in seasonal, pandemic and highly pathogenic influenza viruses. Drugs. 2009;69(18):2523-31.

27. Abed Y, Goyette N, Boivin G. A reverse genetics study of resistance to neuraminidase inhibitors in an influenza $A / H_{1} N_{1}$ virus. Antivir Ther. 2004;9(4):577-81.

28. Influenza - update 114 . Global Alert and Response (GAR). Geneva: World Health Organisation; 20 August 2010. Available from: http://www.who.int/csr/don/2010_08_20/en/index.html

29. Rogers GN, Daniels RS, Skehel JJ, Wiley DC, Wang XF, Higa $\mathrm{HH}$, et al. Host-mediated selection of influenza virus receptor variants. Sialic acid-alpha $2,6 \mathrm{Gal}$-specific clones of A/duck/ Ukraine $/ 1 / 63$ revert to sialic acid-alpha $2,3 \mathrm{Gal}$-specific wild type in ovo. J Biol Chem. 1985;260(12):7362-7.

30. Tumpey TM, Maines TR, Van Hoeven N, Glaser L, Solórzano A, Pappas C, et al. A two-amino acid change in the hemagglutinin of the 1918 influenza virus abolishes transmission. Science. 2007;315(5812):655-9.

31. Preliminary review of $D 222 \mathrm{G}$ amino acid substitution in the haemagglutinin of pandemic influenza $A\left(\mathrm{H}_{1} \mathrm{~N}_{1}\right) 2009$ viruses. Wkly Epidemiol Rec. 2010;85(4):21-2.

32. Kilander A, Rykkvin R, Dudman SG, Hungnes O. Observed association between the HA1 mutation $\mathrm{D}_{222 \mathrm{G}}$ in the 2009 pandemic influenza $A\left(\mathrm{H}_{1} \mathrm{~N}_{1}\right)$ virus and severe clinical outcome, Norway 2009-2010. Euro Surveill. 2010;15(9):pii=19498. Available from: http://www.eurosurveillance.org/ViewArticle. aspx?Articleld $=19498$

33. Puzelli S, Facchini M, De Marco MA, Palmieri A, Spagnolo D, Boros S, et al. Molecular surveillance of pandemic influenza $A\left(H_{1} N_{1}\right)$ viruses circulating in Italy from May 2009 to February 2010: association between haemagglutinin mutations and clinical outcome. Euro Surveill. 2010;15(43):pii=19696. Available from: http://www.eurosurveillance.org/ViewArticle. aspx?Articleld=19696

34. Maines TR, Jayaraman A, Belser JA, Wadford DA, Pappas C, Zeng $\mathrm{H}$, et al. Transmission and pathogenesis of swine-origin $2009 A\left(\mathrm{H}_{1} \mathrm{~N}_{1}\right)$ influenza viruses in ferrets and mice. Science. 2009 24;325(5939):484-7.

35. Shinya K, Ebina M, Yamada S, Ono M, Kasai N, Kawaoka Y Avian flu: influenza virus receptors in the human airway. Nature. 2006;440(7083):435-6. 